ISSN: 2277-3754

ISO 9001:2008 Certified

International Journal of Engineering and Innovative Technology (IJEIT)

Volume 10, Issue 1, July 2020

\title{
PV Based BLDC Motor Driven Air Conditioning System Using MPPT
}

\author{
Chaitanya S. magare ${ }^{1}$, S. S. Dhamse ${ }^{2}$ \\ ${ }^{1}$ M. Tech. Student, Department of Electrical Engineering, Government Engineering College \\ Aurangabad, Maharashtra, India
}

\begin{abstract}
Now a day's solar energy is more essential in our day to day life. For every country power demand is increasing. This paper proposed perturbs and observes $(P \& O)$ method in MPPT for PV array BLDC drive for cooling application. A buck step down converter is used in conjunction with the arduino for proper control to execute MPPT. While equal voltages, as well as power variation, are measured in algorithm, then it allows the superior performance of MPPT in driving motor BLDC. The performance will not be affected even under dynamic conditions due to designing and modeling of the proposed system like the MPPT algorithm for BLDC motor drive, PV array fed air condition.
\end{abstract}

Keywords- BLDC, buck dc/dc converter, perturb and observe (P\&O) method, MPPT, air conditioner compressor.

\section{INTRODUCTION}

Extracted usable electricity from the sun was made possible by the invention of the photoelectric method via a semiconductor device which changes photon energy into electrical energy. Solar energy is the slightest polluting and the most unlimited of all known energy sources. A buck converter in combination with appropriate control is utilized to execute MPPT algorithm by designing of the MPPT algorithm for PV panel using Arduino. The considerable load is an air conditioner. To gather such a variety of loads the solar power should be able to supply to the air compressor, as the result required on the grid is abbreviated. According to several studies, the fastest constant voltageMPPT method is anticipated to track maximum power from solar panel also at the same time PV current, as well as voltage, are used deviation to follow the maximum power point(MPP) of a solar panel below changing irradiance environment has existed.

\section{LITERATURE REVIEW}

In this paper, MPPT technique is executed and discussed to extract maximum power from PV module not including buck or boost converter, therefore condense switching losses and increases efficiency and decreases cost for solar panel feed BLDC Motor-driven air compressor [1]. The MPPT method is chosen to create a resourceful scheme which uses the majority of the input power supplied from the PV panel. From the buck converter and MPPT method the stabilized output is generated to fed in a PMDC motor which can extract maximum power from the input supply. In this paper, they are driving a PMDC motor with better performance of MPPT using Buck converter [2].

Manuscript received: 22 June 2020

Manuscript received in revised form: 18 July 2020

Manuscript accepted: 02 August 2020

Manuscript Available online: 15 August 2020
This paper describes non-switching regions compared with simulation to show and discuss the execution complications of capacitor peak current control perturb and observe MPPT technique. It has been exposed to give very fast transients and also little oscillation in the region of the MPP[3].This paper has obtained a similarity among ten different MPPT techniques in relation to their implementation costs and performance. A ranking of the ten MPPT techniques has been proposed by taking into consideration the study results along with computational costs and hardware, the(IC)and ( $\mathrm{P} \& \mathrm{O})$ methods are the finest rankings [4].This paper permitted new fast active MPPT by the ability of extremely high exact power tracking technique which tracks the total MPPT in shading conditions as well as the efficiency of MPPT was above $99.6 \%$ and the assembly time was below $150 \mathrm{~m} / \mathrm{s}$ [5].R. Faranda has projected MPPT techniques for the PV system, $45 \%$ of energy is produced from the solar panel in the entire globe [6]. This paper describes the efficiency of solar PV module is improved by adding the MPPT method. Incremental conductance algorithm is used with direct current control method. MPLAB IDE software is used to execute simulation as well as the hardware of the system is developed in laboratory [7]. This paper presents PV power generation system with MPPT constant voltage method in voltage operating mode. To get a high output voltage the boost converter is used[8]. This paper describes a $\mathrm{P} \& \mathrm{O}$ algorithm with boost converter and simulates P-V and I-V characteristics of PV module in MATLAB/SIMULINK also shown the maximum efficiency of solar PV module [9]. In this work, under the several load conditions the fuzzy based controller and PID controller are simulated and control the speed of the BLDC motor. To make a system stable therefore PID and fuzzy controllers are used [10].

\section{METHODOLOGY}

The proposed block module for PV based BLDC drive system using MPPT is shown in Fig. 1.

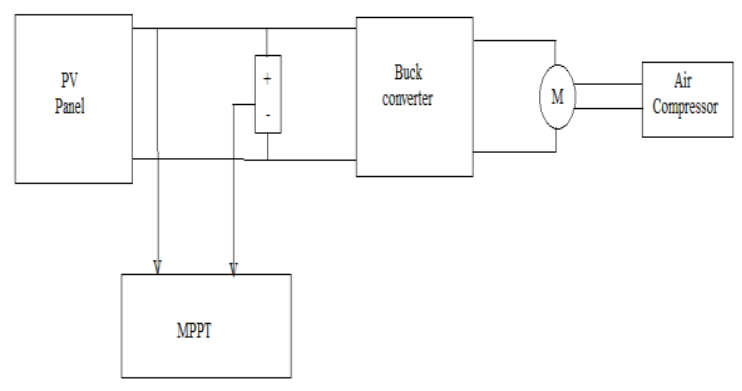

Fig.1. Proposed block diagram 
ISSN: 2277-3754

ISO 9001:2008 Certified

International Journal of Engineering and Innovative Technology (IJEIT)

Volume 10, Issue 1, July 2020

For the BLDC motor required voltage is not known then the buck converter is used as for each necessity of the voltage for the motor in order to start the rated motor speed.

\section{PV ARRAY DESIGN AND MPPT ALGORITHM A. PV array design}

In general PV cells are made up of silicon semiconductor. A slim semiconductor wafer is designed to act as an electric field with negative on one side and positive on another side for solar cells. When the sunlight falls on the solar cells, the electron starts moving. The electrical conductor is placed which is linked to both sides of solar cells to form the electric circuits. The movement of the electron induces the electric current and it was linked to load. On the basis of the structure of the PV cells are in circular or square shape probably as shown in Fig. 2.

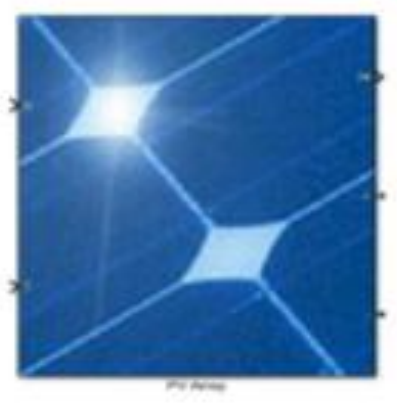

Fig.2. PV array of simulink

The PV cells generate low voltage such as $0.5 \mathrm{~V}$. For high current (I) and high voltage (V), a PV cells are allied in series and parallel to proper output voltage. Equation (1) expresses the current.

$I=I p h-I o\left[\frac{\exp (V+I . R s)}{V T}-1\right]-\left[\frac{\left(V+I_{R} R s\right)}{R p}\right]$

Where,

$=$ Inspolation current

$=$ Current

$=$ Reverse saturation current

$=$ Voltage

$=$ Series resistance

$=$ Parallel resistance

$=$ Thermal voltage

$=$ Temperature In PV cells the power output of Temperature, insulation, load current are more important, equation (2) express the output power of the PV cell.

$$
\text { Po }=f \text { (inst }(2)
$$

The PV cell nonlinear characteristic approach with one diode model by equation (3),

$$
I=I p-I o(\exp (q(V+I R s) / K T)-1)-I s
$$

The standard test condition for the PV module parameters (Temperature $27^{\circ} \mathrm{C}$, irradiance $=1000 \mathrm{~W} / \mathrm{m}^{2}$, air pressure $=$ 1.5) . PV panel specifications are given in Table 1.

\begin{tabular}{|l|c|}
\hline \multicolumn{2}{|c|}{ Table 1. PV panel specifications } \\
\hline Max Power(Pmax) & $20 \mathrm{Wp}$ \\
\hline Max Power Voltage(Vmp) & $18 \mathrm{~V}$ \\
\hline Max Power Current (Imp) & $1.13 \mathrm{~A}$ \\
\hline Short Circuit Current (Isc) & $1.22 \mathrm{~A}$ \\
\hline Open Circuit Current (Voc) & $22 \mathrm{~V}$ \\
\hline Module Efficiency & $>14.5$ \\
\hline Tolerance & $+/-3 \%$ \\
\hline
\end{tabular}

\section{B. MPPT technique}

The solar cell's efficiency is very low and cells are connected together. The maximum power transfer theorem is used for increasing the efficiency of the solar cell or solar panel. The theorem states "Maximum power is transferred from the source to the load when the load resistance is equal to thevenin's equivalent resistance". The thevenin's equivalent is also called solar cell or solar impedance. Therefore, all the MPPT techniques use the theorem to equals the load resistance or impedance of the load to the source [8].

To understand how MPPT works, consider a solar panel. Using PV panel effect solar panel generates power therefore the $\mathrm{P}-\mathrm{V}$ characteristics that has the various operating points of the solar panel and various power output is achieved. The maximum power output is obtaining one exact point of the power-voltage characteristic on the solar panel. This exact point is called the maximum power point (MPP). The MPP modified due to solar irradiation also varies in temperature or any shading effect [9]. Fig. 3 shows the solar PV panel characteristics.

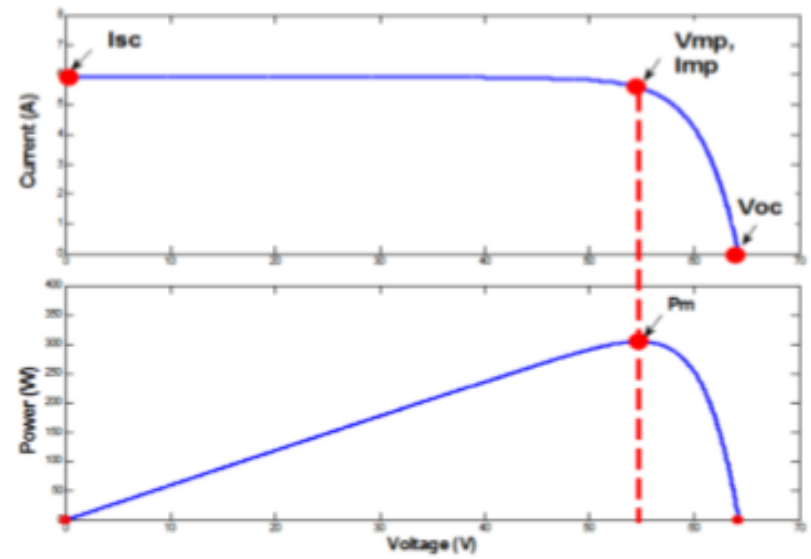

Fig.3. I-V and P-V characteristics of solar pv panel [9]

The implementation of the MPPT requiresa sensor and analog digital converter[2].For the MPPT there are many algorithms.

The MPPT tracking system the most useful methods are as follows [3].

1. Incremental conductance method.

2. Perturb and observe method.

3. Constant voltage method.

4. Short circuit current.

5. Open circuit Voltage.

The efficiency of the incremental conductance method is $98.79 \%$ and the P\&O method efficiency is 98.27\%[7][4]. 


\section{ISSN: 2277-3754 \\ ISO 9001:2008 Certified \\ International Journal of Engineering and Innovative Technology (IJEIT) \\ Volume 10, Issue 1, July 2020}

The most commonly used method is the P\&O. The simulink model of $(\mathrm{P} \& \mathrm{O})$ is shown in Fig. 4.

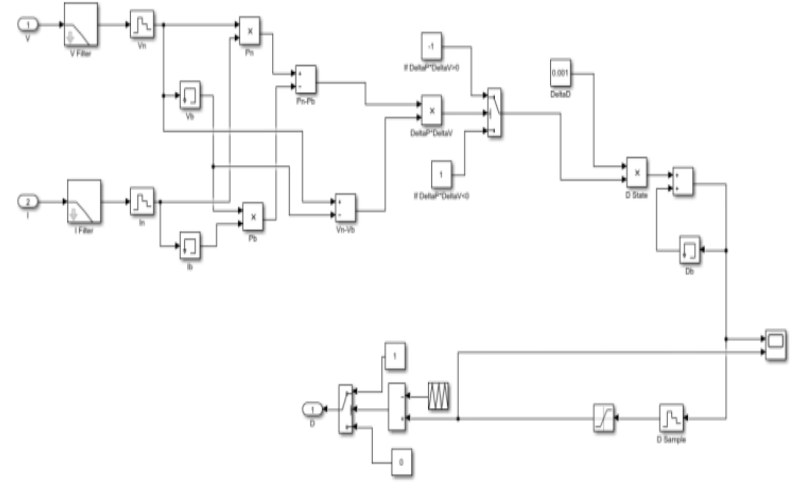

Fig.4. perturb and observe simulink model

The common method isP\&O method. Less number of sensors are used, the operating voltage is sampled and the algorithm is changed the sample voltage in any required direction. The change in sample operating power or voltage is represented as $\mathrm{dp}$ or $\mathrm{dv}$. If thedv and dp goes towards the positive then the voltage increases in the algorithm up to the MPP until dp dv goes into the negative. The iterations are carriedout until the voltage reaches theMPP in perturb and observe algorithm. The voltage is not an exact match to theMPP but it is perturbing around MPP[5]. In this way, the perturbation of the voltage is around theMPP and simultaneously corresponding power is matched to the perturbing cycle [6].Fig. 5 shows the flowchart of $\mathrm{P} \& \mathrm{O}$ algorithm.

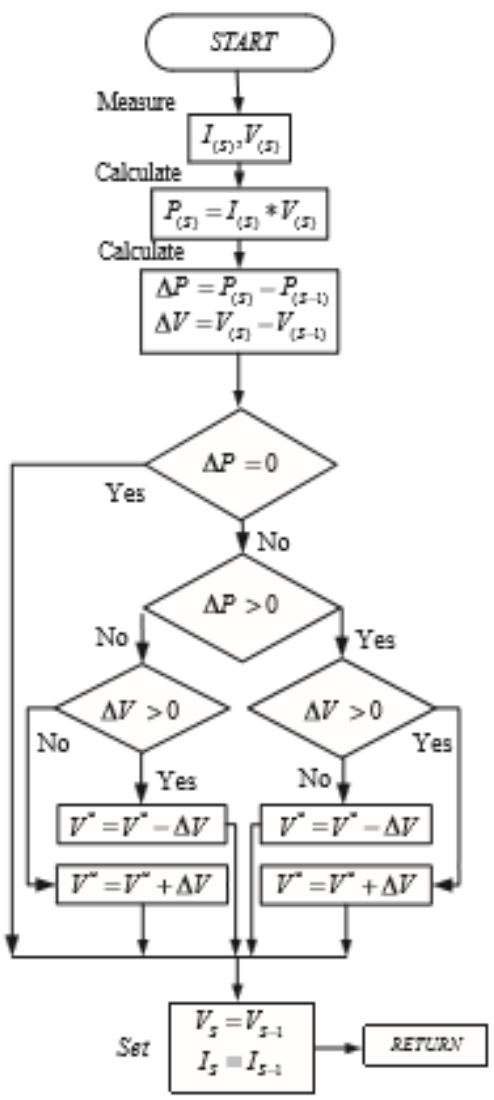

Fig.5.The flowchart ofperturb and observe algorithm [5]
Considering an entire factor, the selected technique is perturbing and observed and it is implemented on the Arduino. Fig. 6 shows the characterises of $\mathrm{P} \& \mathrm{O}$ algorithm as the terminal voltage of PV array.

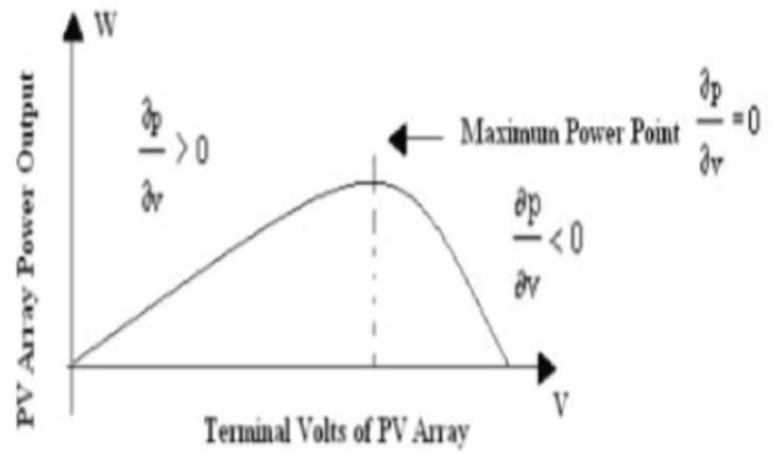

Fig.6. Terminal voltage of PV array [8]

\section{BUCK CONVERTER}

A buck converter in combination with suitableArduinois used to execute MPPT. For driving the BLDC motor the required voltage is necessary therefore the buck converter is used and it is also used as a starter. Buck converter steps down the voltage higher to the lower value [1]. This converter is combined through the PV panel. As per the solar panel output's variation with respect to the change in temperature and irradiation the buck converter steps down the voltage $24 \mathrm{~V}-13 \mathrm{~V}$. Assembly of Buck converter as shown in Fig. 7.

When the Switch Q is on, current flows through the inductor and the inductor stores the energy. Stored energy can transmit to the load from the supply source through the inductor. When switch Q is off, diode become forward biased. The stored energy in the inductor is transferred to the load [2].ON-OFF state of buck converter as shown in Fig. 8. Table 2. Buck converter specifications

\begin{tabular}{|l|c|}
\hline Input Voltage & $6 \mathrm{v}-40 \mathrm{v}$ \\
\hline Output Voltage & $1.3 \mathrm{v}-35 \mathrm{v}$ \\
\hline Output Power & $300 \mathrm{~W}$ \\
\hline Frequency & $300 \mathrm{kHz}$ \\
\hline
\end{tabular}

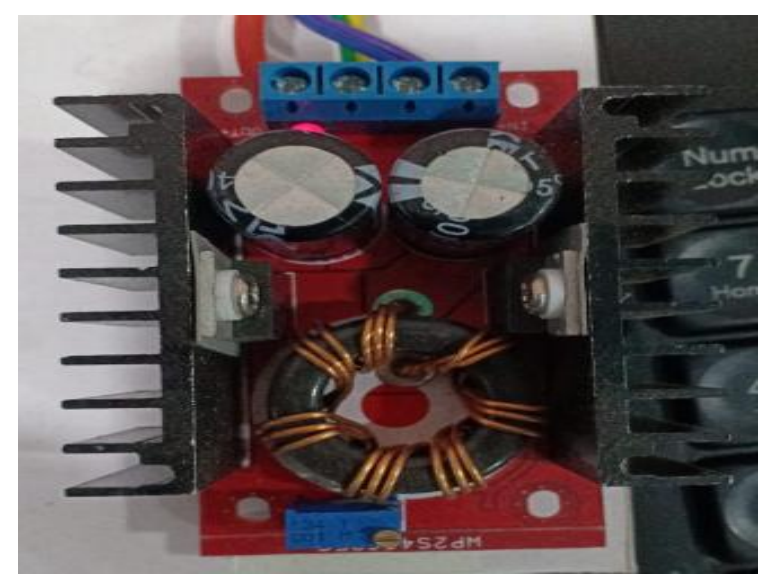

Fig.7.Assembly of buck converter 
ISSN: 2277-3754

ISO 9001:2008 Certified

International Journal of Engineering and Innovative Technology (IJEIT)

Volume 10, Issue 1, July 2020

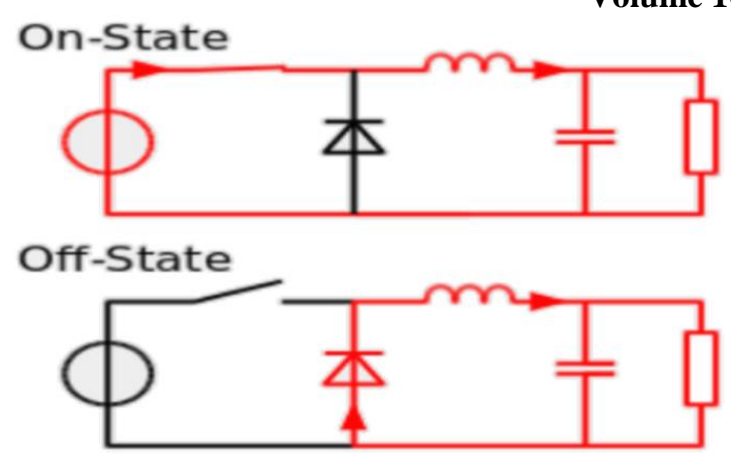

Fig.8. ON-OFF state of buck converter [2]

\section{BLDC MOTOR MODELLING}

The synchronous machine and BLDC motor modeling are developed in a similar manner. Due to some dynamic characteristics being different on the rotor permanent magnet is mounted. From the rotor flux linkage is dependent on the magnetic material. The three-phase voltage source is fed by one structure of BLDC from the three-phase motor, due to this voltage source is not essential to be sinusoidal [10]. Figure 9 shows the assembly of BLDC motor.

Electronic speed control (ESC) system is used to drive a BLDC motor as well as speed control and Hall Effect sensor is also used [10]. The BLDC motor specifications are given in Table 3.

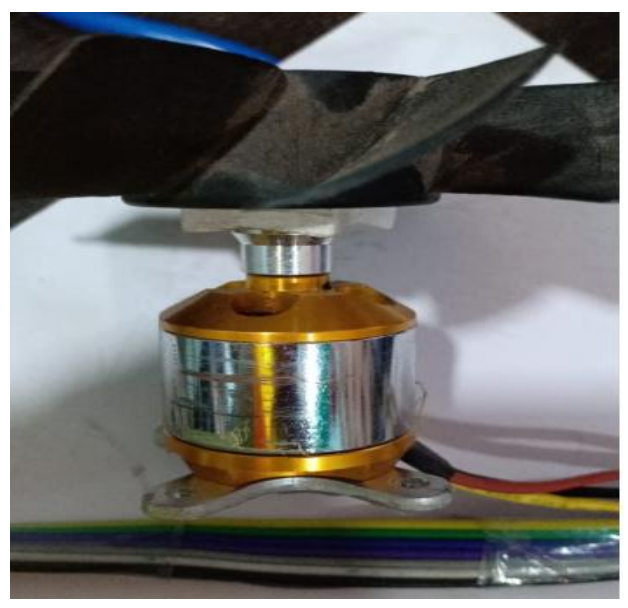

Fig. 9. Assembly BLDC motor

Table 3. BLDC motor specifications

\begin{tabular}{|l|c|}
\hline Parameters & Description \\
\hline Number of Poles & 8 \\
\hline Number of Phase & 3 \\
\hline Speed Constant & $1221 \mathrm{rpm}$ \\
\hline Toque (rated) & $1.4 \mathrm{Nm}$ \\
\hline No Load Speed & $3870 \mathrm{rpm}$ \\
\hline Resistance & $0.363 \Omega$ \\
\hline Inductance & $0.049 \mathrm{~m}$ \\
\hline Mass & $160 \mathrm{~g}$ \\
\hline
\end{tabular}

VII. SIMULATION RESULTS

The primary stage of BLDC motor specifications was defined. For the stabilization of the PV panel output buck converter is used. The buck converter's output is not efficient but it is stabilized. The input power supplied is utilized to make an efficient system from MPPT technique. The combination of buck converter and MPPT technique extract max power from the solar panel and feed the stable output to the BLDC motor. Hence stable output is designed and executed with an effective system.

Along with the BLDC motor all parameters and specifications are checked with MATLAB/SIMULINK. Fig. 10 shows the collective buck as well as the BLDC motor Simulink model.

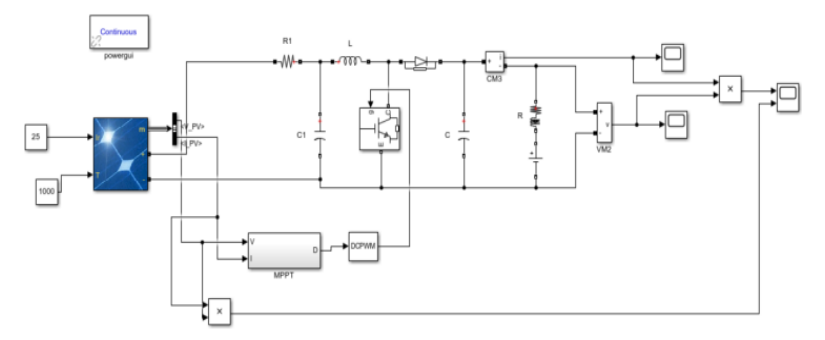

Fig.10. Overall Simulink

Here there are five simulation results from that only one result is shown in Fig. 11. The maximum power(W) with respect to time is shown in Fig. 11 (a) and Fig. 11 (b) shows the maximum current(A) with respect to time. The solar PV module extracts the maximum power is $44.16 \mathrm{~W}$ for maximum voltage $18.4 \mathrm{~V}$ as per simulation results are given in Table 4.

\begin{tabular}{|c|c|c|} 
Table 4. Simulation results \\
\begin{tabular}{|c|c|c|}
\hline $\begin{array}{c}\text { Max Voltage } \\
(\mathrm{v})\end{array}$ & $\begin{array}{c}\text { Max Current } \\
\text { (A) }\end{array}$ & $\begin{array}{c}\text { Max Power } \\
(\mathrm{w})\end{array}$ \\
\hline 6.7 & 2.2 & $14.74 \mathrm{~W}$ \\
\hline 8.9 & 2.3 & $20.47 \mathrm{~W}$ \\
\hline 11.8 & 2.3 & $27.14 \mathrm{~W}$ \\
\hline 14.1 & 2.4 & $33.84 \mathrm{~W}$ \\
\hline 18.4 & 2.4 & $44.16 \mathrm{~W}$ \\
\hline
\end{tabular}
\end{tabular}

(a)

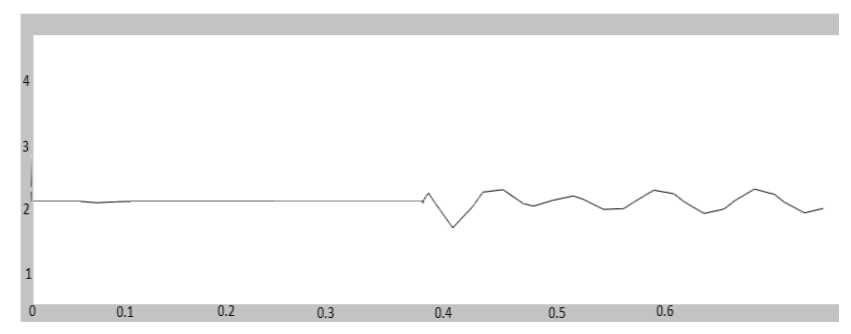

(b)

Fig. 11. Simulation result of a) power and b) current Fig. 12 shows the speed of BLDC motor is $120 \mathrm{rad} / \mathrm{s}$ (1145rpm) and Fig.13 shows the torque of BLDC motor is $1.4 \mathrm{~N}-\mathrm{m}$ it can be observed $600 \mathrm{~W} / \mathrm{m} 2$. 
ISSN: 2277-3754

ISO 9001:2008 Certified

International Journal of Engineering and Innovative Technology (IJEIT)

Volume 10, Issue 1, July 2020

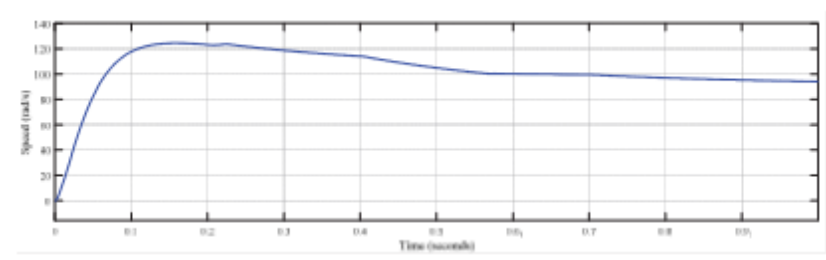

Fig. 12. Speedof BLDC motor

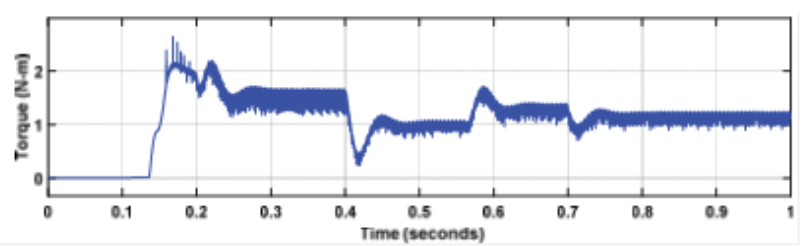

Fig. 13. Torqueof BLDC motor

\section{EXPERIMENTAL RESULT}

PV system for BLDC motor drive with MPPT performance is basically executed. The current sensor is used for calculating the current in MPPT technique. For running the BLDC motor, the three-phase $\mathrm{H}$ bridge MOSFET driver is used. Taking $1100 \mathrm{kv}$ BLDC motor to connect the condenser for the cooling application. The BLDC motor was initially run with constant speed $1221 \mathrm{rpm}$ and the starting torque is $1.4 \mathrm{~N}-\mathrm{m}$ with current is $2.4 \mathrm{~A}$ is obtained. Table 5 gives the max power extract from the solar panel to apply various voltages.

Table 5. Experimental results

\begin{tabular}{|c|c|c|}
\hline $\begin{array}{c}\text { Max voltage } \\
(\mathrm{v})\end{array}$ & $\begin{array}{c}\text { Max current } \\
(\mathrm{A})\end{array}$ & $\begin{array}{c}\text { Max power } \\
(\mathrm{w})\end{array}$ \\
\hline 6.7 & 2 & $13.4 \mathrm{~W}$ \\
\hline 8.9 & 2.1 & $18.69 \mathrm{~W}$ \\
\hline 14.0 & 2.2 & $25.96 \mathrm{~W}$ \\
\hline 11.8 & 2.2 & $31.0 \mathrm{~W}$ \\
\hline 18.4 & 2.3 & $42.32 \mathrm{~W}$ \\
\hline
\end{tabular}

IX. CONCLUSION AND FUTURE SCOPE

Perturb and observeMPPT technique is obtained maximum power from the PV cell as well as simultaneously uses solar panel's current and voltage to track the maximum power point (MPP) of PV panel. Perturb and observe method in MPPT for PV array without any interruption BLDC drive for cooling application. Using MATLAB/SIMULINK various load conditions are examined to the dynamic characteristics like current, voltage and power. Experimental model is designed and simulation results are approximately matched.

\section{REFERENCES}

[1] S.Munisekhar ,Dr.G.V.Marutheswar and Dr.P.Sujatha "The Fastest MPPT Tracking Algorithm for PV Array Fed BLDC Motor Driven Air Conditioning system"ICEES 2019 Fifth International Conference on Electrical Energy systems 21-22 February 2019, SSN College of Engineering, Chennai, India.

[2] Chetanakumar Hadimani S, R Radha, A B Raju and Rohini Jyoti "Photovoltaic Based PMDC Motor Drive System Using MPPT" 2016 IEEE Second International Conference on Cognitive Computing and Information Processing (CCIP).
[3] M.K. Shirazil, M. Joorabin and A. Sadeghi“Intelligent P\&O MPPT Algorithm in PV Stand Alone for Faster Transient Response "International Journal of Energy Engineering, Vol.5. Pp.74-79, 2015.

[4] Dariusz Sobczyński "Simulation Study of Small Isolated Power Electronic Converters for PV System” 2016 IEEE.

[5] Hassan Fathabadi "Novel Fast Dynamic MPPT (Maximum Power Point Tracking) Technique with the Capability of Very High Accurate Power Tracking" Elsevier Journal Energy.Vol.94, pp. 466-475. Jan .2016.

[6] Roberto Faranda, Sonia leva "Energy Comparison of MPPT Techniques for PV Systems" Wseas Transaction on Power system ISSN 1790-5060 Issue 6, Vol.3 2008.

[7] S.S.Valunjkar, S.D.Joshi, N.R.Kulkarni "Implementation of Maximum Power Point Tracking Charge Controller for Renewable Energy" 2014 IEEE International Conference on Advanced Communication Control and Computing Technologies (ICACCCT).

[8] P. Sanjeevi Kumar, G. Grandi and W. Wheeler "A Simple MPPT Algorithm for Novel PV Power Generation System by High Output Voltage DC-DC Boost Converter" 2015 IEEE.

[9] T. Chaitanya, Ch.Saibabu, J.SuryaKumari "Modeling and Simulation of PV Array and its Performance Enhancement Using MPPT (P\&O) Technique" International Journal of Computer Science \& Communication Networks, Vol 1(1), September-October 2011.

[10] P.Suganthi, S.Nagpavithra, S.Umamaheswari "Modeling and Simulation of Closed Loop Speed Control for BLDC Motor" Proc. IEEE Conference on emerging devices and smart system (ICEDSS 2017) 3-4 March 2017. 